\title{
Social and healthcare personnel's self-reported competence in small and medium-sized companies in preparation for simulation coaching
}

\author{
Mari Helena Salminen-Tuomaala*1, Susanna Haapasalmi ${ }^{2}$, Pasi Jaskari ${ }^{2}$, Tomi Tupiini ${ }^{1}$ \\ ${ }^{1}$ Seinäjoki University of Applied Sciences, School of Health Care and Social Work, Finland \\ ${ }^{2}$ Seinäjoki Vocational Education Centre, Seinäjoki, Finland
}

Received: November 16, 2018

Accepted: January 27, 2019

Online Published: January 29, 2019

DOI: $10.5430 /$ cns.v7n2p37

URL: https://doi.org/10.5430/cns.v7n2p37

\begin{abstract}
Purpose: The paper describes staff's self-rated theoretical, practical and interaction competence in 20 social and healthcare companies. The study draws from a research and development project run jointly by two educational institutions and a health technology development center. The results can be used to develop the content of a multiprofessional simulation coaching intervention.

Data and methods: Data were collected in the autumn of 2017 using an online survey software. The quantitative data were analyzed using the SPSS for Windows version 23 and the qualitative data using inductive content analysis. The response rate was $96 \%$ ( $\mathrm{n}=125)$. This article presents the quantitative results.

Results: Respondents found that they were competent in interaction, in identifying their clients' needs, in attending to client safety and in supporting clients' psychosocial and physical function. Their ratings were lower for issues pertaining to severe disability, for encountering aggressive behavior and for some aspects of digitalization.

Conclusions: The most important development needs involved making better use of digital tools and remote counseling, enhancing information technology competence and learning to encounter aggressive behavior.
\end{abstract}

Key Words: Competence, Simulation-based coaching, Simulation-based education, Professional development, Multiprofessional

\section{INTRODUCTION}

This study deals with self-reported competence of staff in small and medium-sized social and healthcare companies in Finland. The requirement of improving staff competence partly has its roots in the need to create more innovative, efficient and sustainable health systems and to facilitate citizens' access to safe and high quality health services, as stressed by the European Union Health Program. ${ }^{[1]}$ Similar aspirations are reflected in national policies. For example in Finland, quality guidelines emphasize the need to provide well-timed services based on needs assessment and implemented by competent personnel. ${ }^{[2]}$ The professionals in social and health care organizations are faced with the requirements of safe client care, multiprofessional collaboration and evidence-based practice. ${ }^{[3]}$ Besides sound staff competence, an open atmosphere is essential for promoting

\footnotetext{
${ }^{*}$ Correspondence: Mari Helena Salminen-Tuomaala; Email: mari.salminen-tuomaala@ seamk.fi; Address: Seinäjoki University of Applied Sciences, School of Health Care and Social Work, Finland.
} 
wellbeing in the working community and for high quality, humane treatment of the clients. Continuous professional development is recognized as an essential element of the work. $^{[4]}$

In many western countries, the social and health organizations face these challenges in an increasingly aging society. Even the staff in small and medium-sized enterprises, such as the ones discussed in this study, will be expected to upgrade their competence base and to engage in more extensive multiprofessional collaboration. Earlier practices many not always be effective for responding to the needs of aging clients with deteriorated functional capacity and multiple simultaneous health or social problems. ${ }^{[5,6]}$ In Finland, the situation is complicated by a major reform underway, anticipated to transform the entire system of health and social services. It has been suggested that the success of the reform largely depends on the development of staff competence levels. ${ }^{[7]}$

The study is part of a research and development project, carried out in collaboration between a university of applied sciences, a vocational education institution and a health technology development center in Finland. The project is funded by the European Social Fund and its purpose is to plan simulation-based education, called coaching in this context, for personnel working in small and medium-sized companies in health and social care industries. The clients of the 20 enterprises involved are old people, children in need of child protection services, or clients with a general learning disability or a mental health disorder. The clients are recipients of various care, rehabilitation and accommodation services.

\subsection{Background}

According to the European Union definition, ${ }^{[8]}$ small and medium-sized companies are enterprises with a staff headcount of 250 or less and a maximum annual turnover of 50 million euro. So far, there has been little research on staff's self-assessed theoretical, practical or interaction competence in such companies in social and healthcare industries. ${ }^{[9,10]}$ Self-assessments are required to gauge competence levels, strengths and development needs in these enterprises. ${ }^{[1]]}$

For the purposes of this article, professional competence is defined as a formally and informally acquired potential and capability to perform in the domain of social and health care $^{[12]}$ It is also seen as a combination of generic and profession-specific skills and knowledge and personality characteristics, molded by the social environment. In social and health care, where ethical awareness and compassion are emphasized as essential elements, competence can be claimed to be centered in the person, which means that the practicing professional needs to be looked at holisti- cally. ${ }^{[12-14]}$ Competence is also contextual or it as a social dimension; it is acquired and constructed in a social context in a community of professionals. ${ }^{[12,15]}$ In other words, this paper adheres to the notion that competence has a technical/factual, personal and social dimension. The technical or factual dimension refers to domain-specific expert knowledge and skills and independent problem-solving. The personal dimension of competence encompasses the ability to assess one's development needs and opportunities and to reach one's potential. This dimension includes qualities like autonomy, reliability, self-confidence and moral-ethical awareness. The social dimension of competence refers to communication and cooperation skills and ability to create social relationships. ${ }^{[16]}$ In recent years, digital literacy and communication skills have grown in importance. ${ }^{[17]}$

The development of staff competence is a challenge for small and medium-sized enterprises. ${ }^{[18]}$ Even in small companies, employers must ensure that their workers reach the necessary competence levels and changing quality requirements. Development efforts are thus essential for both individuals and organizations. Ensuring adequate competence levels calls for collaborative and contextual learning of individuals within organizations, and it can involve professional and personal development. At best, the assessment of competence and learning needs can open up new possibilities for enterprises preparing for future requirements. Besides field-specific skills and knowledge, staff members' learning to learn skills may require an update. ${ }^{[19]}$

Staff's multiprofessional collaboration skills are crucial in small and medium-sized companies, where they can benefit clients by leading to more holistic overall care and nursing. ${ }^{[20]}$ Collaboration calls for adapting roles and taking into consideration the other professional groups at the workplace, and it involves sharing knowledge, skills and responsibilities. ${ }^{[21]}$ Better care outcomes can be reached if representatives of various professions become committed to collaboration and mutual respect. ${ }^{[22]}$ The sense of community and cooperative development of skills and knowledge must be emphasized in small or medium-sized enterprises especially. Ideally, learning takes place in intensive interaction, in which professionals can cross borders together. ${ }^{[13]}$

Special attention should be paid to pedagogical approaches and learning environments when planning educational interventions for working life. Many skills, such as interaction, collaboration and teamwork skills, may be best learnt through action-based methods. ${ }^{[23-25]}$ Simulation pedagogy carried out with multiprofessional small groups can help participants understand each other's roles and responsibilities ${ }^{[26,27]}$ and facilitate sharing good practices. At the heart of learning lies 
an evolving companionship, through which added value can be gained. ${ }^{[13]}$

Good simulation coaching starts with the learners' clearly defined needs and it is carried out in as authentic a context as possible using an action-based approach. Simulation enables the learning of various competences in a holistic and experiential manner ${ }^{[28]}$ and it can increase participants' confidence in their skills, whether technical or nontechnical. ${ }^{[29-31]}$ Simulation can be used to improve client safety, ${ }^{[32,33]}$ for example by focusing on situational sensitivity and problem-solving skills, which are essential in preventing near misses. ${ }^{[34,35]}$ It can be useful when practicing acute, recurrent or rare situations, and even in learning empathy skills. ${ }^{[27]}$

An encouraging atmosphere and constructive feedback discussions are important for successful simulation coaching. Participants have an opportunity to look for a shared understanding of the situation or for alternative solutions together. ${ }^{[27]}$ Positive learning experiences and appreciation from peers and facilitators can increase learners' selfconfidence and multiprofessional collaboration skills. ${ }^{[31,36]}$

\subsection{Purpose and aim}

The study purpose was to describe personnel's self-reported theoretical, practical and interaction competences in social and healthcare companies before their participation in a simulation-based coaching intervention. The study aimed at gathering knowledge that can be useful in the future when contents are planned and developed for coaching multiprofessional groups by means of simulation.

\section{The research questions were:}

- How do staff in small and medium-sized social and healthcare companies rate their theoretical competence?

- How do staff in small and medium-sized social and healthcare companies rate their practical competence?

- How do staff in small and medium-sized social and healthcare companies rate their interaction competence?

\section{RESEARCH METHODS}

\subsection{Data collection}

The study was conducted in twenty small and medium-sized social and healthcare companies, which specialize in serving old people, children in need of child protection services and clients with a general learning disability or a mental health disorder. Data collection took place in a region with a population of 200,000 in the autumn of 2017. An online survey software (Webropol) was used to collect the data.
The questionnaire was developed on the basis of a systematic literature review and a preliminary competence survey from spring 2017, conducted in small and medium-sized companies. In an effort to ensure that the instrument was valid, or measured that aspect of the phenomenon under study that it was supposed to measure, ${ }^{[37]}$ the questionnaire was pretested by a group consisting of project partners, members of the steering group and company staff members $(n=14)$. The questionnaire was found to be appropriate and easy to understand. The test group found the questions unambiguous. Each item asked only one piece of information, and the instrument measured what it was supposed to measure.

Besides background questions, the questionnaire included both qualitative $(n=4)$ and quantitative $(n=44)$ items, 31 of which were Likert type questions. The background questions concerned respondents' sex, age, education and occupation. In addition, the participants were requested to select which of the options presented was closest to their job description. The background data are presented in Table 1 using frequency and percentage distributions.

Table 1. Demographic data on the respondents

\begin{tabular}{lll}
\hline Background variable & n & \% \\
\hline Age & & \\
under & 40 & 32 \\
$40-49$ & 37 & 30 \\
50 or older & 44 & 35 \\
Sex & & \\
female & 104 & 84 \\
male & 19 & 15 \\
Education & & \\
general secondary education & 11 & 9 \\
vocational qualification & 37 & 30 \\
college & 40 & 32 \\
university/university of applied sciences & 35 & 28 \\
Job description & & \\
administrative & 27 & 22 \\
counseling & 64 & 51 \\
promotion of clients' functional capacity & 88 & 70 \\
assisting clients with basic activities of daily living & 77 & 62 \\
supporting clients' growth and development & 45 & 36 \\
\hline
\end{tabular}

The Likert type items were divided into the following batteries of questions: Self-rated theoretical competence $(n=9)$; self-rated practical competence $(n=10)$ and self-rated interaction competence $(n=4)$. The purpose of the qualitative items was to collect data on the staff members' individual learning needs and on the organization's collaborative learning needs regarding simulation. The results of the quantitative data analysis are discussed in this article. 
The Moodle learning platform, used for the project communication, was employed to inform the target group of the study. The staff of the 20 companies also received the information, invitation to take part in the survey and the questionnaire via email. The fact that participation was voluntary and anonymous was emphasized in the accompanying letter. Using the online tool made the results rapidly available for further processing in Excel and statistics software (SPSS).

\subsection{Data analysis}

SPSS for Windows 23 was used to analyze the data. One of the investigators undertook this task, but all authors commented on the results. ${ }^{[38]}$ Measures of central tendency were used to present participants' self-rated competence on a Likert-type scale, ranging from 1 (very good) to 5 (very poor). The respondents were organized into categories by age, sex, educational background and job description for a Mann-Whitney U test comparison. The three age categories were under 40, 40-49 and 50 or older. The four educational categories included general education, vocational qualification, college and university. (Colleges, or professional college level qualification, were phased out by Bachelor level education in universities of applied sciences over 20 years ago.) Last, the categories for participants' job descriptions or scope of responsibility involved administrative; counseling; promotion of clients' functional capacity; assisting clients with basic activities of daily living; supporting clients' growth and development; other (please specify).

The Mann-Whitney U test was used to search for statistically significant differences in participants' self-reported theoretical, practical and interaction competences.

\subsection{Research ethics, validity and reliability}

The researchers made an effort to observe the ethical guidelines as recommended by the Helsinki Declaration ${ }^{[39]}$ and the National Board on Research Integrity in Finland. ${ }^{[40]}$ Participation was voluntary and based on informed consent and on information disseminated through the project platform and personal e-mails addressed to potential participants. Respondents remained anonymous and could not be identified based on their responses. ${ }^{[40]}$ As participants were not requested to name the enterprise they worked for, the anonymity of the organizations was also protected. ${ }^{[41]}$

Research validity and reliability were evaluated, considering the data collection, measurement and results in turn. The Webropol online survey tool was selected to ensure an adequate sample size. ${ }^{[42,43]}$ The high response rate obtained (96\%) increased the reliability of the study. No sampling criteria were employed for the staff in the enterprises, but every staff member had an equal opportunity to participate. The sample can be considered representative of the population in a region of 200,000 citizens, where the number of small and medium-sized social and healthcare companies is limited. Sample representativeness and external validity were further increased by the fact that the study was conducted in a homogenous country with a population of 5.5 and with uniform national health and social service policies. The data were carefully analyzed and the report was illustrated by tables. ${ }^{[41]}$ As the data were skewed and unevenly distributed, the Mann-Whitney U test was selected for analysis. ${ }^{[37]}$

The methods used were evaluated from the perspective of face or "common sense" validity and content validity with help of 14 pre-testers. There were no obvious confounding variables, so the study can be considered internally valid. The investigators also reflected on whether the data, methods and results justified the conclusions and whether the conclusions reached were meaningful and useful. ${ }^{[37]}$

The reliability of the study was examined from the perspective of consistency across the questionnaire items already during the pre-testing. The purpose was to ensure that the questions were adequately objective to be understood similarly by the test group members, and as intended by the investigators. Despite all efforts, the relatively simple analysis can be considered a methodological limitation in this study.

\section{RESULTS}

This section first gives an overview of the demographic data on the respondents (see Table 1) and then proceeds to presenting their self-rated theoretical, practical and interaction competences (see Table 2). Theoretical competence refers to knowledge required to identify and respond to various client needs and situations. Practical competence consists of skills required to select appropriate interventions and technology to support clients and families, among other things. Interaction competence involves team and group work skills and awareness of group dynamics.

\subsection{Demographic data on the participants}

The response rate in this study was $96 \%(\mathrm{n}=125)$. As shown in Table 1, 84\% $(\mathrm{n}=104)$ of all participants were women and $15 \%(\mathrm{n}=19)$ men. Two respondents $(1 \%)$ did not indicate whether they were female or male. The age range was 23-64 years; $32 \%(n=40)$ of the participants were under 40 years old, $30 \%(n=37)$ were $40-49$ years old and $35 \%(n=44)$ were 50 or older. Four respondents did not give their age.

Most respondents in this study had either a vocational qualification (30\%), a professional college level qualification $(32 \%)$ or a degree from a university/university of applied 
sciences $(28 \%)$. A minority $(9 \%)$ only had a general edu- vices $(15 \%, \mathrm{n}=19)$, public health nursing $(6 \%, \mathrm{n}=7)$ or cation background; they had graduated from a senior high school, elementary or comprehensive school or their older equivalents. Two respondents did not reply the question. elderly care $(2 \%, \mathrm{n}=3)$. In addition, 18 participants had a qualification or degree in some other field. As shown in Table $1,22 \%$ of the respondents held an administrative position.

More specifically, the participants held a vocational quali- Table 2 presents respondents' self-rated theoretical, practification in practical nursing $(47 \%, \mathrm{n}=59)$, or a Bachelor's cal and interaction competences using means, medians and degree/ its predecessor in nursing $(15 \%, \mathrm{n}=19)$, social ser- modes.

Table 2. Respondents' self-rated theoretical, practical and interaction competences

\begin{tabular}{|c|c|c|c|}
\hline & Means & Median & Mode \\
\hline \multicolumn{4}{|l|}{ Theoretical competence } \\
\hline Knowledge of simulation-based learning & 4.01 & 4.00 & 5 \\
\hline Knowledge required in identifying client needs for care and nursing & 1.89 & 2.00 & 2 \\
\hline Knowledge required in counseling clients on issues related to psychosocial function & 2.23 & 2.00 & 2 \\
\hline Knowledge required in counseling clients on issues related to physical function & 2.09 & 2.00 & 2 \\
\hline Knowledge required in counseling clients on chronic illness & 2.43 & 2.00 & 2 \\
\hline Knowledge required in counseling clients on acute illness & 2.57 & 2.00 & 2 \\
\hline Knowledge of issues related to severe disability & 3.11 & 3.00 & 3 \\
\hline Knowledge of how to act in acute situations & 2.42 & 2.00 & 2 \\
\hline Knowledge of how to encounter violent client behavior & 2.57 & 2.00 & 2 \\
\hline \multicolumn{4}{|l|}{ Practical competence } \\
\hline Skills required in selecting appropriate caring interventions in various situations & 2.20 & 2.00 & 2 \\
\hline Skills required in selecting optimal interventions in acute situations & 2.45 & 2.00 & 2 \\
\hline Skills required in selecting appropriate means of encountering defiant or violent behavior & 2.50 & 2.00 & 2 \\
\hline Skills required in supporting clients in conflict situations & 2.35 & 2.00 & 2 \\
\hline Skills required in supporting clients' families & 2.31 & 2.00 & 2 \\
\hline Skills required in attending to client safety & 1.92 & 2.00 & 2 \\
\hline Skills required in observing social changes to develop client work & 2.68 & 3.00 & 3 \\
\hline Skills required in using digital tools for counseling & 3.05 & 3.00 & 3 \\
\hline Skills required in remote counseling & 3.48 & 3.00 & 3 \\
\hline \multicolumn{4}{|l|}{ Interaction competence } \\
\hline Interaction skills & 1.70 & 2.00 & 2 \\
\hline Team and groupwork skills & 1.67 & 2.00 & 2 \\
\hline Empathy skills & 1.60 & 2.00 & 2 \\
\hline Skill to identify factors that affect group dynamics & 2.11 & 2.00 & 2 \\
\hline
\end{tabular}

Note. Scale: 1 = very good; 2 = fairly good; 3 = neither good nor poor; 4 = fairly poor; and 5 = very poor

\subsection{Staff members' self-rated theoretical competence}

\subsubsection{Knowledge of simulation-based learning}

Only 3 respondents in the small and medium-sized companies involved in this study had some experience of simulationbased education. None of the respondents rated their knowledge of simulation-based learning as good, and only $8 \%$ found that their competence was fairly good. The majority of the respondents found that their theoretical competence regarding simulation-based learning was fairly poor (35\%) or very poor (37\%). In addition, $20 \%$ chose the option "neither good nor poor".

The staff members' job description seemed to be connected with their self-rated knowledge of simulation-based learning; respondents in administrative positions found their knowledge slightly better than other staff members $(p=.032)$. 


\subsubsection{Knowledge required in identifying client needs for care and nursing}

Almost one fourth, or $24 \%$ of the respondents, thought that their knowledge of identifying client needs for care and nursing were was good, and $64 \%$ rated their knowledge as fairly good. The remaining $12 \%$ found their knowledge neither good nor poor or very or fairly poor. Women's ratings were slightly higher than men's $(p=.044)$.

\subsubsection{Knowledge required in counseling clients on func- tional capacity}

When inquired about counseling clients on psychosocial function, $68 \%$ of the respondents rated their knowledge as fairly good and $7 \%$ as very good. A fifth or $20 \%$ felt that their knowledge was neither good nor poor, and $5 \%$ found their knowledge very or fairly poor. No significant differences were detected between men and women or between age groups, educational levels or job descriptions.

Similarly, the majority of the respondents found that their knowledge of counseling clients on issues pertaining to physical function was either very good (18\%) or fairly good (58\%). Over one fifth, or $22 \%$, reported that their knowledge was neither good nor poor, and $2 \%$ rated their knowledge as fairly poor.

\subsubsection{Knowledge required in counseling clients on their illness}

Respondents were also asked how they rated their knowledge of counseling clients on issues related to chronic illness. Their responses were fairly good (49\%); neither good nor poor $(30 \%)$; fairly poor $(10 \%)$; very good $(10 \%)$; and very poor $(1 \%)$. A comparison by age revealed a nearly significant difference between the under 40-year-old and the over 50 -year-old respondents, who scored higher $(p=.047)$. Second, there was a statistically significant difference between educational levels. Graduates from the older, now phased-out college-level professional education rated their knowledge as higher than respondents with a vocational qualification $(p=.005)$ or respondents with a degree from a university of applied sciences $(p=.018)$. Third, a statistically significant difference $(p=.002)$ was also observed between those involved in assisting clients with basic activities of daily living and the other groups. Respondents working in basic care of clients scored higher.

The results were similar for respondents' knowledge of counseling clients on issues related to acute illness, with $9 \%$ of the participants rating their knowledge as very good, $42 \%$ as fairly good and $35 \%$ as neither good nor poor. The remaining $14 \%$ rated their knowledge to be poor. Again, a nearly significant difference $(p=.019)$ was discovered between age groups, with the over 50 -year-old respondents rating their knowledge higher than the under 40-year-olds. The educational background of the respondents was also connected with the ratings. Graduates from the college-level professional education found their knowledge better than individuals with the lower vocational qualification $(p=.003)$ or individuals with a degree from a university of applied sciences $(p=.015)$. These differences were statistically significant. Finally, the difference between those involved in basic care and the other groups was also statistically significant $(p=.012)$. The respondents who worked in basic care rated their knowledge higher.

\subsubsection{Knowledge of how to act in acute situations}

Respondents' ratings for this item were very good knowledge (8\%); fairly good knowledge (53\%); neither good nor poor knowledge (28\%); fairly poor knowledge (10\%) and very poor knowledge (1\%). As above, regarding knowledge required in counseling clients on issues related to their illness, respondents with a college-level professional education had a higher opinion of their knowledge of acute situations than respondents with a vocational qualification $(p=.044)$.

It was also discovered that individuals holding administrative positions rated their knowledge of dealing with acute situations slightly higher than the other professional groups $(p=$ .021). A statistically significant difference was detected between those whose work involved supporting clients' growth and development and the other groups $(p=.008)$, with the first group scoring higher.

\subsubsection{Knowledge of severe disability}

Respondents had less knowledge of severe disability compared to other aspects of theoretical competence; $35 \%$ of the participants rated their knowledge as very poor, $36 \%$ as neither good nor poor, $25 \%$ as fairly good and only $4 \%$ as very good. Comparison by age, sex, education and job description did not show significant differences in the respondents' ratings.

\subsubsection{Knowledge of encountering violent client behavior}

Almost half of the respondents, $48 \%$, found that they had fairly good knowledge of encountering violent client behavior. The second greatest group (28\%) reported that their skills were neither good nor bad, while the rest said their knowledge was either fairly poor (16\%), very good $(6 \%)$ or very poor $(2 \%)$.

There was a statistically significant difference between men and women; men rated their knowledge higher than women $(p=.000)$. A nearly significant difference $(p=.023)$ was detected between two age groups; the under 40-year-old respondents $(p=.023)$ had a higher opinion of their knowledge of how to encounter violent client behavior compared to the 
age group 40-49. In addition, those individuals, whose main responsibilities involved supporting clients' growth and development, had higher ratings than the other groups ( $p=$ $.000)$.

\subsection{Staff members' self-rated practical competence} 3.3.1 Skills required in selecting appropriate interventions The majority of the staff members participating in this study reported that they had fairly good $(68 \%)$ or very good $(10 \%)$ skills required in selecting appropriate interventions to meet clients needs. The next greatest group or $16 \%$ found that their skills were neither good nor poor. The remainder said that their skills were very poor $(5 \%)$ or fairly poor $(1 \%)$.

As regards selecting optimal interventions in acute situations specifically, most participants again rated their skills as fairly good $(51 \%)$ or very good $(6 \%)$. Almost one third $(32 \%)$ felt that their skills were neither good, nor poor, and the remaining $8 \%$ and $3 \%$ thought that their skills were fairly poor or very poor. Comparison by age, sex, education and job description did not produce any statistically significant differences.

The results were similar, when staff members were inquired how well they were able to select appropriate means of encountering defiant or aggressive client behavior. The greatest group of respondents thought that their skills were fairly good $(49 \%)$ or very good $(6 \%)$, with the remaining participants rating their skills as neither good nor poor (30\%), fairly poor $(12 \%)$ or very poor $(3 \%)$. Men were more confident than women about finding appropriate means to approach defiant or aggressive clients. The difference was statistically significant $(p=.000)$. In addition, respondents involved in supporting clients' growth and development had higher ratings than the other groups $(p=.010)$.

\subsubsection{Skills required in supporting clients and family members}

Most respondents felt that they were competent in supporting clients in conflict situations (fairly good skills $53 \%$ and very good skills $10 \%$ ). Less than one third, $27 \%$, said that their skills in this respect were neither good nor poor, but $8 \%$ selected the option "very poor" and $2 \%$ the option "fairly poor". Statistical analysis revealed a significant difference; again those involved in supporting clients' growth and development had higher ratings than the other groups ( $p=.007)$. Age, sex, education or job description did not have any significant association with respondents' self-rated client support skills.

Similar ratings were obtained for respondents' self-reported competence in supporting clients' family members: fairly good skills $61 \%$; very good skills $8 \%$; neither good nor poor

Published by Sciedu Press skills $20 \%$; fairly poor skills $9 \%$; and very poor skills $2 \%$. A statistically significant difference was detected between individuals, who had graduated from professional college-level education, compared to respondents with a vocational qualification $(p=.006)$. The first group of respondents mentioned had higher ratings. Secondly, those holding administrative positions, felt slightly more competent in this respect than other professionals $(p=.031)$. Respondents' age and sex had no statistically significant association with their self-reported skills in supporting family members.

\subsubsection{Skills required in attending to client safety}

The results showed that respondents felt confident about their ability to ensure client safety. The majority, $62 \%$, rated their skills as very good and $22 \%$ as fairly good. The rest or $16 \%$ said that their skills were neither good nor poor, which means that none of the respondents considered their client safety skills poor. There were no statistically significant differences between the various groups of respondents.

\subsubsection{Skills required in observing social changes}

Respondents' ratings for skills required in observing changes occurring in society were as follows: very good $46 \%$; fairly good 5\%; neither good nor poor $46 \%$ and fairly poor $3 \%$. Statistical analysis revealed a significant difference between non-administrative employees and administrative staff members, who rated their skills higher $(p=.009)$.

\subsubsection{Skills required in using digital tools for counseling}

The greatest group among the respondents, $46 \%$, assessed their skill level in using digital tools for counseling as neither good nor poor, and $29 \%$ rated their skills as fairly poor. The other rates were fairly good $24 \%$ and very good $1 \%$. Comparison by age, sex, education and job description did not reveal statistically significant differences between the respondents.

\subsubsection{Skills required in remote counseling}

Rather similar to the results on the use of digital tools above, $41 \%$ of the respondents felt that their skills in remote counseling were neither good nor poor and $29 \%$ that their skills were fairly poor. In addition, $16 \%$ reported very poor skills and $12 \%$ fairly good skills. Only one person chose the option "very good skills". No statistically significant differences were detected in the comparison between the various groups of respondents.

\subsubsection{Information technology skills}

Respondents' ratings regarding their skills to use various applications were fairly evenly distributed around the medium scale: fairly good $27 \%$; neither good nor poor $28 \%$; and fairly poor $25 \%$. The rest rated their skills as very good (9\%) or very poor $(11 \%)$. Men reported more confidence in the use of applications than women; the difference was statistically 
significant $(p=.015)$. Moreover, a nearly significant difference ( $p=.019$ ) was detected between the under 40-year-old and over 50-year-old respondents. The younger age group exhibited higher ratings.

Respondents' ratings did not differ much from the above as regards their technological communication skills; fairly good $29 \%$; neither good nor poor $30 \%$; and fairly poor $23 \%$. A minority of respondents said that their technological communication skills were very good $(9 \%)$ or very poor $(9 \%)$ Again, there was a statistically significant male-female difference in that men scored higher than women $(p=.016)$ and a statistically significant between the same age groups as above. In other words, the under 40-year-old respondents rated their skills higher than over 50-year-old respondents ( $p$ $=.003)$.

When inquired about their skills in using social media, respondents responded as follows: fairly good $36 \%$; neither good nor poor $30 \%$; and fairly poor skills $18 \%$. Few respondents found their skills very good $(9 \%)$ or very poor (7\%). Consistently, when compared with the results on the use of applications in general and on technological communication skills, men scored higher than women $(p=.006)$ and the under 40-year-old respondents higher than the over 50 -year-olds $(p=.001)$. It was also discovered that staff members with a degree from a university of applied sciences had slightly higher ratings than respondents with a vocational qualification or graduates from professional college-level education. The differences were not statistically significant, however. Finally, employees involved in basic client care rated their skills in the use of social media lower that the other groups of employees $(p=.024)$.

Respondents were also asked to assess how skillful they were in using the Moodle learning environment. The greatest group, $43 \%$ of the respondents, found their skills very poor, and $28 \%$ felt that their skills were neither good nor poor. The rest found their skills either fairly good $(22 \%)$ or very good $(7 \%)$. The ratings were similar, irrespective of age, sex, education or job description.

\subsection{Interaction competence}

In general, the respondents found that they had solid interaction competence. The majority reported fairly good (55\%) or very good $(36 \%)$ interaction skills. None of the respondents chose the option "fairly poor" or "very poor", but $9 \%$ found that their interaction skills were neither good nor bad.

The results for self-rated team and groupwork skills were: fairly good (59\%); very good (36\%); and very poor (5\%) and for empathy skills fairly good (47\%); very good (46\%), very poor $(6 \%)$; and fairly poor $(1 \%)$.
The last question concerned respondents' self-rated ability to recognize factors that had an effect on group dynamics. Again, most respondents rated their skills as fairly good $(53 \%)$ or very good $(18 \%)$. In addition, $26 \%$ found their skills neither good nor poor, and only $3 \%$ said their skills very or fairly poor. Respondents with a university of applied sciences degree scored higher than staff members with a vocational qualification. The difference between these two groups was statistically significant $(p=.009)$. Finally, respondents whose work involved supporting clients' growth and development, rated their ability to identify factors that affected group dynamics as higher than respondents with different responsibilities $(p=.006)$.

\section{Discussion}

This paper is connected to a multiprofessional project, which produces action-based simulation coaching for small and medium-sized companies, based on the staff members' carefully defined learning needs. Although of current interest, there is still a relatively limited body of research knowledge on the topic. Simulation pedagogical interventions tailored for enterprises are a novelty, both regionally and nationally. This article introduces staff's self-rated theoretical, practical and interaction competences in 20 regional companies. What is important about this project is that the planning has started with the identification of learning needs and that authentic environments will be used for the actual simulation-based coaching.

According to the results, the personnel in the small and medium-sized companies were mostly confident about their theoretical competence as regards recognizing clients' care needs and counseling clients on psychosocial and physical function. However, a considerable number of respondents (35\%) rated their knowledge pertaining to severe disability as very poor. Earlier research confirms that attending to clients with severe disability, who have more special needs compared to other clients, has been found challenging among social and health care professionals. ${ }^{[4]}$ Secondly, respondents in this study found that they had poor knowledge of how to encounter violent client behavior. Simulation-based coaching, which can be useful in promoting emotional intelligence, situational sensitivity and interaction skills, might help address these client situations. ${ }^{[34,35]}$

The respondents in this study reported good practical competence in interaction, in attending to client safety, in supporting clients and in selecting suitable interventions, but identified some development needs in the area of digital skills. Almost one third $(29 \%)$ of the staff members found that they had fairly poor skills in remote counseling and in the use of digital counseling tools. With the increasing digitalization and 
use of mobile technology, a change of attitude and arranging training to help learn these skills should become an important part of the agenda in social and health care organizations. In Finland, for example, the social and healthcare reform is likely to increase the use of digital services. Earlier studies confirm that digital competence requirements have increased and have often been experienced as a challenge by social and healthcare professionals. ${ }^{[45,46]}$ Mobile technology can, however, save time, as patients will not always need to see medical experts, but can consult them through mobile devices. ${ }^{[4,48]}$ Simulated workshops can provide an opportunity for practicing digital remote counseling in a flexible manner.

In addition to poor digital skills, approximately one third of all respondents in this study reported fairly or very poor skills in the use of applications, social media and technological communication. As was probably to be expected, the under 40-year-old respondents reported better skills than the older staff members. The relatively high age of professionals in social and healthcare industries in Finland has earlier been linked with obstacles in using information technology. ${ }^{[49]}$

\section{REFERENCES}

[1] European Union Health Programme 2014-2020 [Internet]. Available from: https://ec.europa.eu/health/programme/policy/2 014-2020_en

[2] Laatusuositus hyvän ikääntymisen turvaamiseksi ja palvelujen parantamiseksi 2017-2019. [Quality recommendation to guarantee a good quality of life and improved services for older persons 2017-19] (in Finnish) [Internet]. Sosiaali- ja terveysministeriö [The Ministry of Social Affairs and Health in Finland.]; 2017. Available from: http : //urn.fi/URN : ISBN : 978-952-00-3960-8

[3] Koulutuksella osaamista asiakaskeskeisiin ja moniammatillisiin palveluihin. Ehdotukset hoitotyön toimintaohjelman pohjalta. [Competence in customer-focused and multi-professional services through education] (in Finnish) Sosiaali - ja terveysministeriö [The Ministry of Social Affairs and Health in Finland.]; 2012. Sosiaali - ja terveysministeriön raportteja ja muistioita 7 .

[4] ICN. The ICN code of ethics for nurses 2012. [Internet] Available from: http://www.icn.ch/images/stories/documents/ about/incode_english.pdf

[5] Weller JM, Barrow M, Gasquoine S. Interprofessional collaboration among junior doctors and nurses in the hospital setting. Med Educ. 2011; 45(5): 478-87. PMid:21414024. https ://doi.org/10.111 $1 / j \cdot 1365-2923.2010 .03919 \cdot x$

[6] Tuomela K, Heikkilä K, Haapanen H, et al. Moniammatillinen oppiminen yhteistyöosaamisen edistäjänä terveydenhuollossa. (In Finnish, with English abstract.) Hoitotiede [Journal of Nursing Science]. 2017; 29(4): 264-75.

[7] Holli K, Saloranta A. Osaaminen tulevaisuuden sote-maailmassa. [Competence in the future world of the social and healthcare reform] (in Finnish); 2016. Available from: http://www.pilkahdus.fi /sites/default/files/tuso-hanke_loppuraportti.pdf

Published by Sciedu Press
Poor technological skills, in turn, have been reported to result in lower motivation and feelings of inadequacy. It has been proposed that social and healthcare professionals should be motivated to practice and use technology by reminding them that the innovations will facilitate their work in the future. ${ }^{[50]}$

\section{Conclusion}

The results of this study can be used to plan multiprofessional simulation coaching interventions. Workshops, skills workshops and full-scale simulations are suggested to respond to the needs of social and healthcare personnel in small and medium-sized enterprises. The results can be equally useful for providers of simulation-based education targeted at medical and nursing staff in various other organizations nationally and internationally. Special attention should be paid to advancing staff's digital and information technological skills.

\section{CONFLICTS OF INTEREST Disclosure}

The authors declare they have no competing interests.
[8] European Commission. What is an SME. Last update 2018. Available from: http://ec.europa.eu/growth/smes/business-frien dly-environment/sme-definition_en

[9] Mulder M. Competence development: some background thoughts. J Agric Educ Extens. 2001; (4): 147-58.

[10] Katwalo AM. An overview of competence development in SMEs. Int J Strat Change Manag. 2006; 1(1/2): 89-95. https ://doi .org/10 .1504/IJSCM. 2006.011104

[11] Nikkanen P. Effectiveness and improvement in a learning organization. In E. Kimonen (Ed.), Curriculum approaches. Jyväskylä: University of Jyväskylä. Department of Education and Institute for Educational Research; 2001: 55-76.

[12] Lewis T. Measuring and certifying skill and competence in the Caribbean: Some conceptual and practical issues. Caribb Curric. 2013; 21: 149-70.

[13] Helakorpi S. Osaaminen ja sen tunnistaminen työelämän ja koulutuksen yhteisenä haasteena. [Recognition of learning as a common challenge for practice and education.] (In Finnish) 2009; Ammattikorkeakoulujen verkkojulkaisu. UAS Journal. Available from: https://arkisto.uasjournal.fi/osaaja_2009-4/H elakorpi\%20PDF.pdf

[14] Hanhinen T. Työelämäosaaminen: Kvalifikaatioiden luokitusjärjestelmän konstruointi. [Working life skills and knowledge: the Construction of the qualification classification system] (In Finnish, with English abstract). Dissertation. University of Tampere; 2010. Available from: http://acta.uta.fi/pdf/978-951-44-8290-8.p df

[15] Collin K. Työssä oppiminen. [Learning at work]. In K. Collin \& S. Paloniemi (Eds.) Aikuiskasvatus tieteenä ja toimintakenttinä. [Adult education, science and practice ] (in Finnish) Jyväskylä: PSKustannus; 2007: 123-54. 
[16] Clarke L, Winch C. A European skills framework?-But what are skills? Anglo-Saxon versus German concepts. Journal of Education and Work. 2006; 19(3): 255, 269.

[17] Eriksson E, Korhonen T, Merasto M, et al. Sairaanhoitajan ammatillinen osaaminen. [Nurses' professional competence] (in Finnish) Sairaanhoitajakoulutuksen tulevaisuus - hanke Ammattikorkeakoulujen terveysalan verkosto ja Suomen sairaanhoitajaliitto ry. Porvoo: Bookwell Oy; 2015.

[18] Holopainen A, Korhonen A, Hakulinen-Viitanen T, et al. Metasynthesis and evidence-based health care- a method for systematic review. Scand J Caring. 2013; 27: 1027-34. PMid:23167699. https://doi.org/10.1111/scs. 12003

[19] Kokko N, Herrala M, Ahola M, et al. Osaamisen kehittäminen pkyrityksissä. [Developing competence in SMEs.] (in Finnish) Helsinki: Työministeriö [Ministry of Labour]; 2000.

[20] Petri L. Concept analysis of interdisciplinary collaboration. Nurs Forum. 2010; 45(2): 73-82. PMid:20536755. https://doi.org/ $10.1111 / \mathrm{j} .1744-6198.2010 .00167 . \mathrm{x}$

[21] Payne M. Teamwork in multiprofessional care. New York: Palgrave; 2000.

[22] Kenny G. The importance of nursing values in interprofessional collaboration. Br J Nurs. 2002; 1: 65-8. PMid:11826322. https : //doi.org/10.12968/bjon.2002.11.1.9328

[23] Boyd AM, Jackson ML. An effective model for rapid skills acquisition through a simulation-based integrated learning environment. J Educ Comput Res. 2004; 30(1\&2): 1-21. https://doi.org/10.2 190/E8CN-91GX-R6WA-Y05N

[24] Jacobs BL. Teaching and learning negotiation in a simulated environment. Widerer L J. 2008; 18: 91-112.

[25] Salminen-Tuomaala M, Kangasluoma E, Kurunsaari MT, et al. Social and healthcare staff's self-reported simulation learning needs in small and middle-sized enterprises. Clin Nurs Stud. 2018; 6(3): 46-56. https ://doi .org/10.5430/cns . v6n3p46

[26] Miller A, Morton S, Sloan P, et al. Can a single brief intervention improve participants' readiness for interprofessional learning? J Interprof Care. 2013; 27(6): 532-3. PMid:23802734. https: //doi.org/10.3109/13561820.2013.805736

[27] Salminen-Tuomaala M, Jaskari P, Perälä S, et al. Nursing and medical staff's experiences of simulation education. Clin Nurs Stud. 2017; 5(4): 73-80. https ://doi.org/10.5430/cns . v5n4p73

[28] Hansen J, Bratt M. Competence acquisition using simulated learning experiences: a concept analysis. Nurs Educ Perspect. 2015; 36(2): 102-7. PMid:29194134. https : //doi .org/10.5480/13-1198

[29] Cooper S, Cant R, Porter J, et al. Simulation based learning in midwifery education: a systematic review. Women Birth. 2012; 25(2): 6478. PMid:21489894. https://doi.org/10.1016/j.wombi. 20 11.03 .004

[30] March AL, Adams MH, Robinson C. Student characteristics and perceptions of learning and confidence acquisition associated with simulation. Nurs Educ Perspect. 2014; 35(5): 335-6. PMid:25291932. https://doi.org/10.5480/12-998.1

[31] Dieckmann P, Patterson M, Lahlou S, et al. Variation and adaptation: learning from success in patient safety-oriented simulation training. Adv Simul. 2016; 2(21): 1-14.

[32] Issenberg SB, Mcgaghic WC, Petrusa ER, et al. Features and uses of high-fidelity medical simulations that lead to effective learning: a BEME systematic review. Med Teach. 2005; 27: 10-28. PMid:16147767. https ://doi.org/10.1080/01421590500046 924

[33] Jeffries PR. Signs of maturity. Simulations are growing and getting more attention. Nurs Educ Perspect. 2015; 36(6): 358-9. https : //doi.org/10.5480/1536-5026-36.6.358
[34] Duff B. Creating a culture of safety by coaching clinicians to competence. Nurse Educ Today. 2013; 33(10): 1108-11. PMid:22726347. https://doi.org/10.1016/j.nedt. 2012.05.025

[35] Forneris SG, Neal DO, Tiffany J, et al. Enhancing clinical reasoning through simulation debriefing: a multisite study. Nurs Educ Perspect. 2015; 36(5): 304-10. PMid:26521499. https ://doi.org/10.548 $0 / 15-1672$

[36] Buckley S, Hensman M, Thomas S, et al. Developing interprofessional simulation in the undergraduate setting: experience with five different professional groups. J Interprof Care. 2012; 26(5): 362 9. PMid:22594349. https://doi.org/10.3109/13561820.201 2.685993

[37] Hirsjärvi S, Remes P, Sajavaara P. Tutki ja kirjoita. [Investigate and write] Helsinki: Kustannusosakeyhtiö Tammi; 2009.

[38] Graneheim UH, Lundman B. Qualitative content analysis in nursing research: concepts, procedures and measures to achieve trustworthiness. Nurse Educ Today. 2004; 24(2): 105-12. PMid:14769454. https://doi.org/10.1016/j.nedt.2003.10.001

[39] Helsinki Declaration World Medical Association Declaration of Helsinki - Ethical principles for medical research involving human subjects (1964), last amended in October 2013. Available from: https://www.wma.net/policies-post/wma-declaration -of-helsinki-ethical-principles-for-medical-resea rch-involving-human-subjects/

[40] TENK Finnish Advisory Board on Research Integrity Responsible conduct of research and procedures for handling allegations of misconduct in Finland 2012. (In Finnish, Swedish and English). Available from: http://www.tenk.fi/files/HTK_ohje_2013.pdf

[41] Burns N, Grove S. The practice of nursing research. Appraisal, synthesis and generation of evidence. 6th ed. Missouri: Saunders Elsevier, Missouri; 2009.

[42] Baruch Y, Holtom BC. Survey response rate levels and trends in organizational research. Hum Relat. 2008; 61(8): 1139-60. https : //doi.org/10.1177/0018726708094863

[43] Hamilton MB. Online survey response rates and times: background and guidance for industry. J Travel Res. 2003; 49(1): 121-35.

[44] Kivistö P. Kolme ja yksi kuvaa osallisuuteen Monimenetelmällinen tutkimus vaikeavammaisten ihmisten osallisuudesta toimintana, kokemuksena ja kielenkäyttönä. [Three and one images of participation. A multimethod study on the participation of severely disabled people: functional participation, experience and language] [An academic dissertation]. (in Finnish with English abstract). Acta Electronica Universitatis Lapponiensis 150. Lapin yliopisto Yhteiskuntatieteiden tiedekunta; 2014.

[45] Laine M, Kokkinen L, Kaarlela-Tuomaala A, et al. Sosiaali- ja terveysalan työolot 2010 [The working conditions of social and health care staff 2010] (in Finnish with English abstract). Kahden vuosikymmenen kehityskulku. Tampere: Tampereen Yliopistopaino Oy - Juvenes Print; 2010.

[46] Vesterinen ML. Suosituksia sosiaali- ja terveysalan koulutuksen kehittämiseen. [Recommendation for the development of social and healthcare education]. In M-L. Vesterinen (Ed.) SOTE-ENNAKOINTI sosiaali- ja terveysalan sekä varhaiskasvatuksen tulevaisuuden ennakointi. [Preparing for the social and healthcare reform - anticipating the future of social and health care and early childhood education] (in Finnish). Iisalmi: Painotalo Seiska Oy; 2011: 116-8.

[47] Chan V, Ray P, Parameswaran N. Mobile e-Health monitoring: an agent-based approach. IET Commun. 2008; 2(2): 223-30. https : //doi.org/10.1049/iet-com:20060646

[48] Leikas L. Sosiaali- ja terveyspalveluiden henkilöstön osaaminen mobiiliteknologioiden hyödyntämisessä asiakastyössä. [The competence of social and healthcare staff in using mobile technologies in 
client work. [A Master's thesis.] Kasvatustieteiden laitos Jyväskylän yliopisto; 2017.

[49] Suhonen L, Ahtiainen M, Siikanen T. Hyvinvointiteknologia sosiaalija terveysalan koulutuksessa. [Welfare technology in social and healthcare education] in L. Suhonen \& T. Siikanen (Eds.) Hyvinvointiteknologia sosiaali- ja terveysalalla - hyöty vai haitta? [Welfare technology in social and health care-a benefit or a disadvantage?] (in Finnish) Tampere: Tampereen yliopistopaino Oy; 2006: 21-31.
[50] Melkas H, Raappana A, Rauma M, et al. Teknologian käytön sudenkuopat sosiaali- ja terveysalan organisaatiossa. [The pitfalls of using technology in social and healthcare organizations]In L. Suhonen \& T. Siikanen (Eds.) Hyvinvointiteknologia sosiaali- ja terveysalalla - hyöty vai haitta? [Welfare technology in social and health carea benefit or a disadvantage?] (in Finnish) Tampere: Tampereen yliopistopaino Oy; 2007: 50-63. 